\title{
Study of the Sustainable Water Resources Management at the Upper Euphrates Basin, Iraq
}

\author{
Sura Mohammed Sameer ${ }^{*}$, Ayad Sleibi Mustafa ${ }^{2}$, Jumaa A. Al-Somaydaii ${ }^{1}$ \\ ${ }^{1}$ Department of Dams and Water Resources Engineering, College of Engineering, University of Anbar, Ramadi 31001, Iraq \\ ${ }^{2}$ Civil Eng. Department, College of Engineering, University of Anbar, Ramadi 31001, Anbar, Iraq
}

Corresponding Author Email: sura_ded@uoanbar.edu.iq

https://doi.org/10.18280/ijdne.160210

Received: 23 July 2020

Accepted: 10 February 2021

\section{Keywords:}

WEAP model, management of water, upper

Euphrates, sustainability

\begin{abstract}
This study aims at developing the aspect of sustainable management of water resources in the part of the upper Euphrates basin to extend the year 2035 by using the Water Evaluation and Planning (WEAP) model. Water budget was developed to assess the current water conditions for the reference year 2015 based on available water supply and the increasing demand for water uses. Some of the proposed scenarios have been applied to the WEAP model. The results showed that the total water demand in 2015 was 100 MCM, and it will rise to $400 \mathrm{MCM}$ in 2035 . With the emergence of a water deficit, it is expected that $38 \mathrm{MCM}$, will be fully provided by applying modern irrigation methods. However, when applying the wastewater reuse scenario, it was found that the water deficit reaches $35 \mathrm{MCM}$. On the other hand, the water deficit has been approximately decreased to $16 \mathrm{MCM}$ when the groundwater scenario was used as an additional source of water supply. The results confirmed the necessity of adopting alternative methods to reduce the water deficit, as well as the ability of the WEAP model to represent the study area.
\end{abstract}

\section{INTRODUCTION}

Planning and management water resources are one of the most important natural elements for all economic and social development especially in arid and semiarid region like Iraq country. Increased demand for water has led to an increase in problems with upstream countries that built dams and reservoirs on rivers, which led to reducing Iraq's water inflows. Thereby creating a gap between supply and demand, and this increased global concerns about the expected future water shortage [1]. Water resources in Iraq suffer from a complex problem consisting of two parts, one is the decrease of Iraq's water inflows, and the other is the poor management of water resources [2].

The Iraqi central and local governments must find quick and prudent solutions as a top priority that includes sustainable management of water resources whose absence causes insufficient Iraq's water share as well as desertification caused by diminishing usable water resources. This is what helps to find Local and scientific solutions instead of moving to neighboring countries to find solutions to water problems [3]. The researchers stressed the importance of managing the available water resources in the most recent ways and means and address this issue in various aspects. Metobwa et al. [4] tried to find ways to get rid of the excessive use of water in the Mara River located in Kenya. Sarhan [5] conducted a study of water resources in the Raqqad basin in Syria in order to improve its management. Sanjaq [6] used the WEAP program to develop methods of managing water resources in Ramallah. Jaradat [7] showed the impact of political and economic stability on the management of water resources in Palestine. Jaber [8] The WEAP model was used to assess the method of the current and future water resources management in the Shatt
Al-Hillah Basin. Al-Eisa [9] was used WEAP to manage water resources in the Najaf Sea. Rasul and Askar [10] prepared a study on water resource management in the Alana Valley in Iraqi Kurdistan using the WEAP program. Mourad [11] used marginal and virtual water in order to achieve a water balance in Syria and increase the individual's share. Al-Ali [12] assessed the water situation in the Great River Basin in Syria. Hussein and Al - Weshah [13] used the WEAP program in order to diagnose the causes of water shortage in the Jordan Valley basin and find the best solutions to this problem.

The main objective of this study was to develop the methods of sustainable management of water resources in the upper Euphrates basin by analyzing water supplies and needs, using WEAP model which is based on forecasting available water resources to extend to 2035. This paper will address basic information about water resources in Anbar, the availability and policy of water resources and suggest solutions to meet the expected water shortages and limited supply.

\section{MATERIALS AND METHODS}

\subsection{Study area}

The Upper Euphrates region is part of Anbar Province in western Iraq. It represents the northern and northeastern part of the Province and constitutes about $23 \%$ of its land. As the area of Anbar Province is equal to (138288) $\mathrm{Km}^{2}$ as explained by Ihab Latif (2012). The Upper Euphrates region consists of five districts (Heet, Haditha, Anah, Rawa, and Qa'im). Its astronomical position between $\left(33^{\circ} 00^{\prime} 0\right.$ " to $35^{\circ} 0^{\prime} 0$ "') $\mathrm{N}$ and $\left(41^{\circ} 0^{\prime} 0^{\prime \prime}\right.$ to $\left.43^{\circ} 0^{\prime} 0^{\prime \prime}\right) \mathrm{E}$, as shown in Figure 1 . The study area is characterized by being of a plateau nature and a dry climate 
whose surface tends to be flat, except for some hills of up to 400 MASL, the upper Euphrates region also contains valleys that give the surface a characteristic ripple. And it gradually descends as we go from northwest to southeast. The study area contains gypsum and calcareous soils in addition to the flood soils that are located on the banks of the Euphrates River. The climate of the study area is semi-desert, as it is characterized by less rainfall and different day time temperatures. Its northern borders with Nineveh Governorate, its eastern borders with Salah al-Din, its southern borders with the district of Ramadi, and its western borders with the district of al-Rutba. Its climate is dry, with precipitation from (121 to 167) $\mathrm{mm}$ in the winter season as explained by the Iraqi General Authority for Meteorology. The population of the Upper Euphrates region in 2015 is $(425,453)$ person, with a natural growth rate of $2 \%$, of whom about (251831) person lived in urban centers. (173622) person in villages and rural areas.

The part of the upper Euphrates basin at Anbar Province has been chosen for the study which represents the region of entry of the Euphrates River into Iraq, and this part to reflect the water reality of all areas that depend on the waters of the Euphrates River.

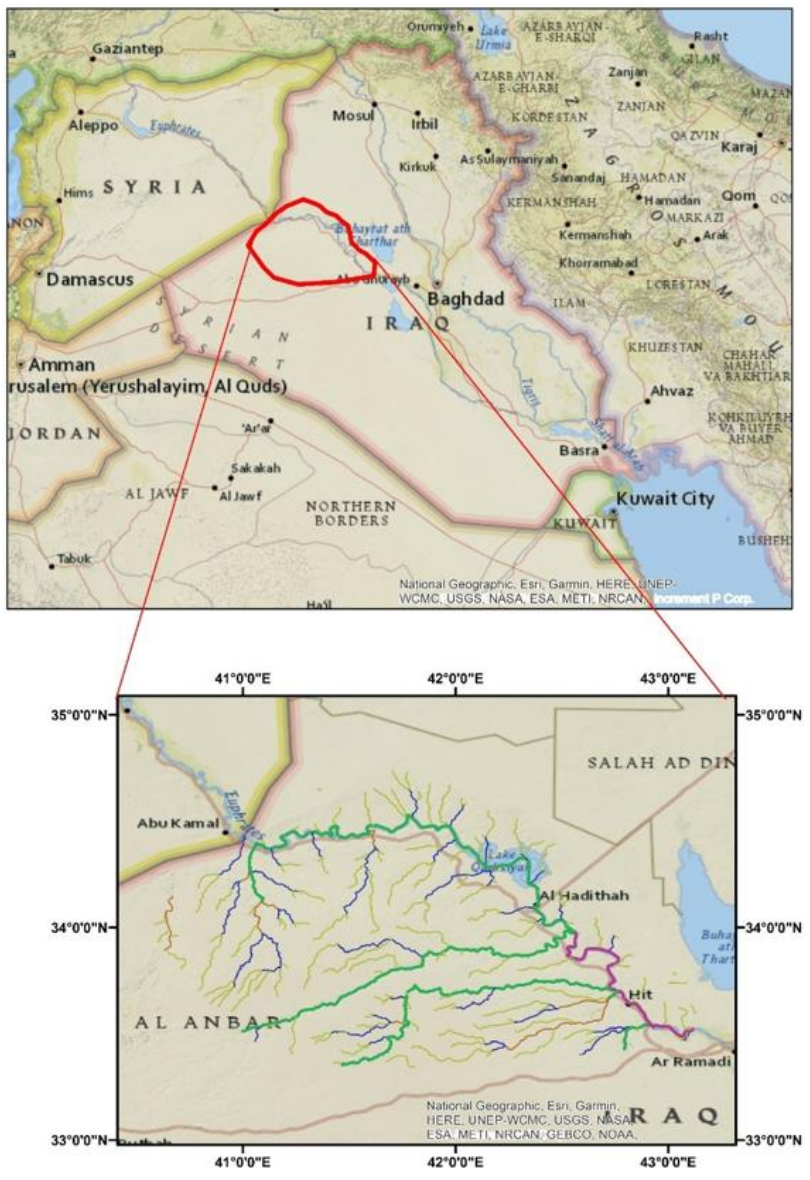

Figure 1. The study area

\subsection{Water resources in the study area}

The water resources available in the upper Euphrates region are either traditional resources represented by surface and ground water or unconventional resources represented by wastewater reuse.

\subsubsection{Conventional water resources}

(1) Surface water

Surface water is represented by water in rivers and lakes.
The study area depends on the Euphrates River mainly, which passes through its lands from the northwest to the southeast. As for the lakes, they are represented by a Hadithah lake, which is the second largest lake in Anbar, with a total area of $480 \mathrm{~km}^{2}$ and a total storage capacity of $8.4 \mathrm{BCM}$, when the water level in the reservoir is at 148 MASL [14]. The Iraqi National Center for Water Management clarified the percentages of water received by Iraq at the Al-Qa'im station. And by comparing the population of the study area, which equals $26 \%$ of the population of Anbar Province, and comparing the area of its land, which is equal to $23 \%$ of the territory of Anbar Province, the share of the study area from the inflow of the Euphrates River received into Iraq was determined equal to $4 \%$ as shown in Figure 2.

\section{(2) Groundwater}

Groundwater is one of the important water sources that has been found in porous sedimentary rocks. The main groundwater source is from rainwater leakage under the ground, which can be considered the main feeder of groundwater. It may appear in the form of springs or eyes. Moreover, groundwater can be used for different purposes to meet human and agricultural demand. Most of those who can use it, are residents of areas where surface water is not available [15].

\subsubsection{Unconventional water resources}

The non-conventional resources are represented by the use of wastewater, which is the water produced from various human activities. The quality of this water has been negatively affected due to human activity on it. It is either black wastewater that needs to be treated in special treatment plants, or gray water that needs initial treatment, and then it is used for irrigation, for example [11].

\subsection{WEAP model}

The Water Evaluation and Planning (WEAP) model is a tool for assessing and planning water resources and is developed by the Stockholm Environment Institute in Boston in the United States of America [16]. It is an easy-to-use tool to helpmate decision makers in developing water management options. It relies on water budget equations where it studies supply-side issues such as groundwater, current flow, reservoirs and transportation operations water. On the other hand, studies water demand side issues such as regions of agricultural, industrial, and household demand, reuse, and prices [11]. WEAP program components are divided into contracts and links, the contract represents the locations of water demand and the links that transfer the water, as shown in Figure 3 [17]. The model also has the ability to simulate the natural and engineering components of systems such as pollution tracking, water quality study, hydroelectric generation, water sustainability, and reuse. It connects sectors, the study of groundwater, ways for supplying it from rain, and the requirements of the ecosystem. The WEAP model also helps in calculating future projections of water demand, calculating projected water deficit ratios, and helping to choose the best alternative that contributes to reducing water deficit ratios [18]. It thus gives a more comprehensive view of many factors that must be taken into account in the management of water resources to ensure their availability now and in the future. WEAP can analyze various cases such as climate change, watershed conditions and projected water demand [19]. 


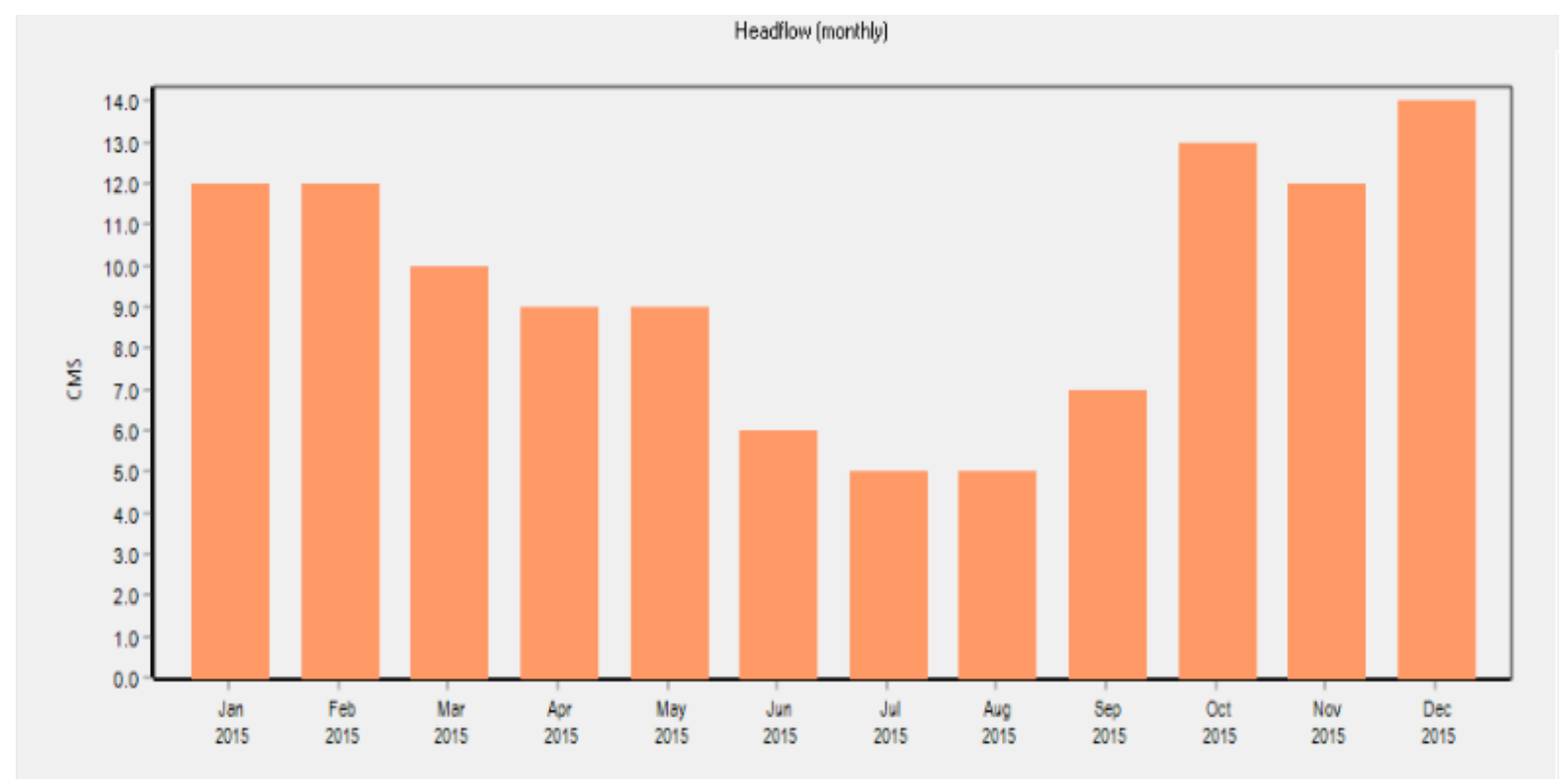

Figure 2. The values of the Euphrates River flow (2015)

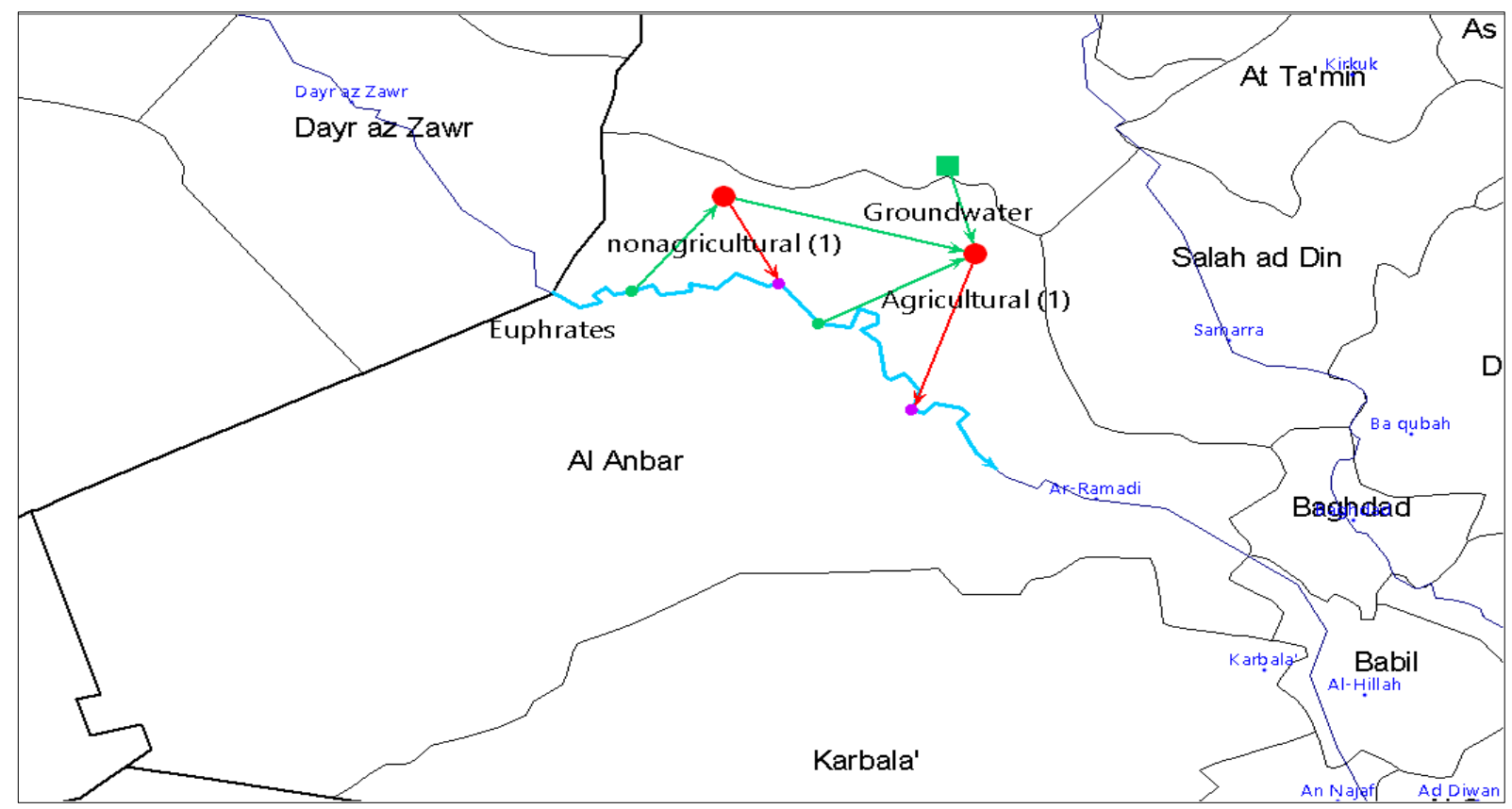

Figure 3. Schematic diagram of the model within the WEAP program

\section{THE DEMAND FOR WATER IN THE UPPER EUPHRATES BASIN}

Water demand in the upper Euphrates region is represented by agricultural and non-agricultural demand.

\subsection{Agriculture irrigation demand}

Agricultural water demand in Iraq represents one of the highest demands. The percentage of consumption in this sector is about $(85 \%)$ of the total water consumption [20]. Irrigation methods used is one of the main reasons for high agricultural water demand because its impact on the losses of water in addition to their direct impact on productivity Each method of irrigation has efficiency in transfer, application, and production. Therefore, the selection of appropriate irrigation methods requires adopting more efficient means and the highest productivity. Because Anbar generally went through a war against ISIS militants, a large development plan was not implemented in agricultural lands. Therefore, the area of agricultural lands in the year 2015 was (5000 dunums) only (1250 hectares) [21]. JICA predicted that the agricultural areas from Al-Qaim to Heet in the year 2035 will be 106,000 dunams, equivalent to 26,500 hectares. The demand for water for the study area will be $262 \mathrm{MCM}$, so the annual demand for water will be equal to $2479.25 \mathrm{~m}^{3} /$ dunam $\left(9917 \mathrm{~m}^{3} /\right.$ hectare). Various types of summer and winter crops are grown in the study area, such as wheat, barley, fruit trees, date palm trees, in addition to summer and winter vegetables [22]. Figure 4 shows the monthly variance in the consumption of agricultural lands. 


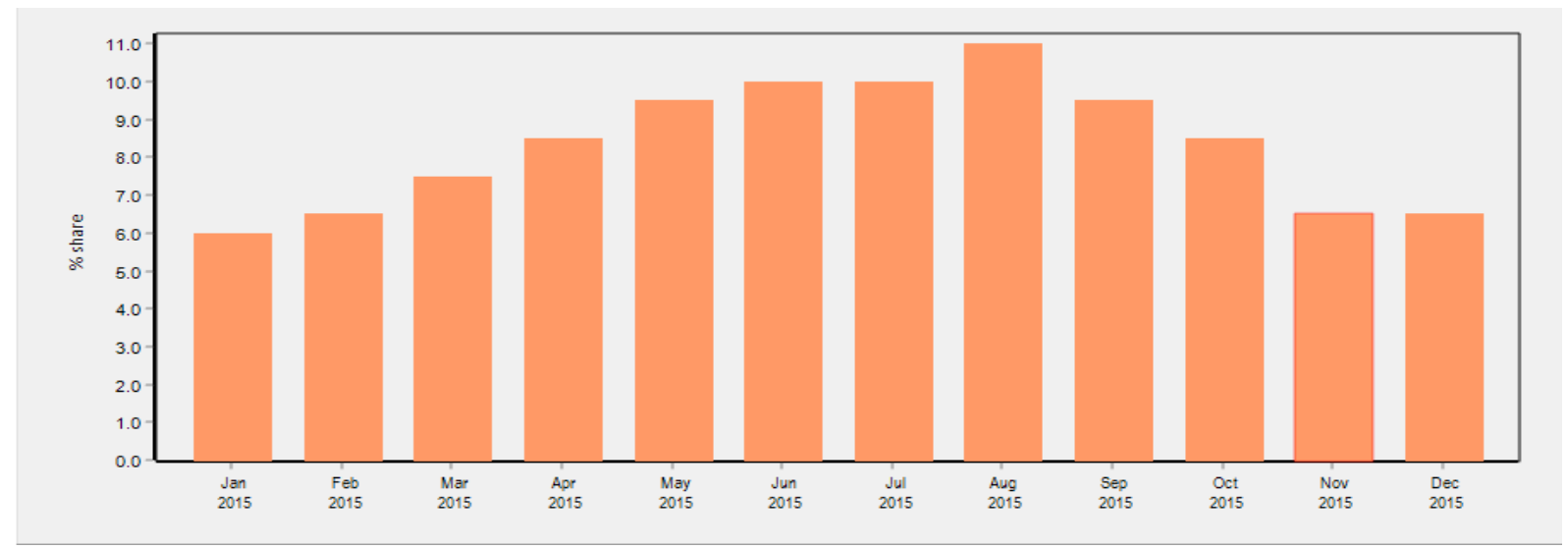

Figure 4. Agricultural monthly variation

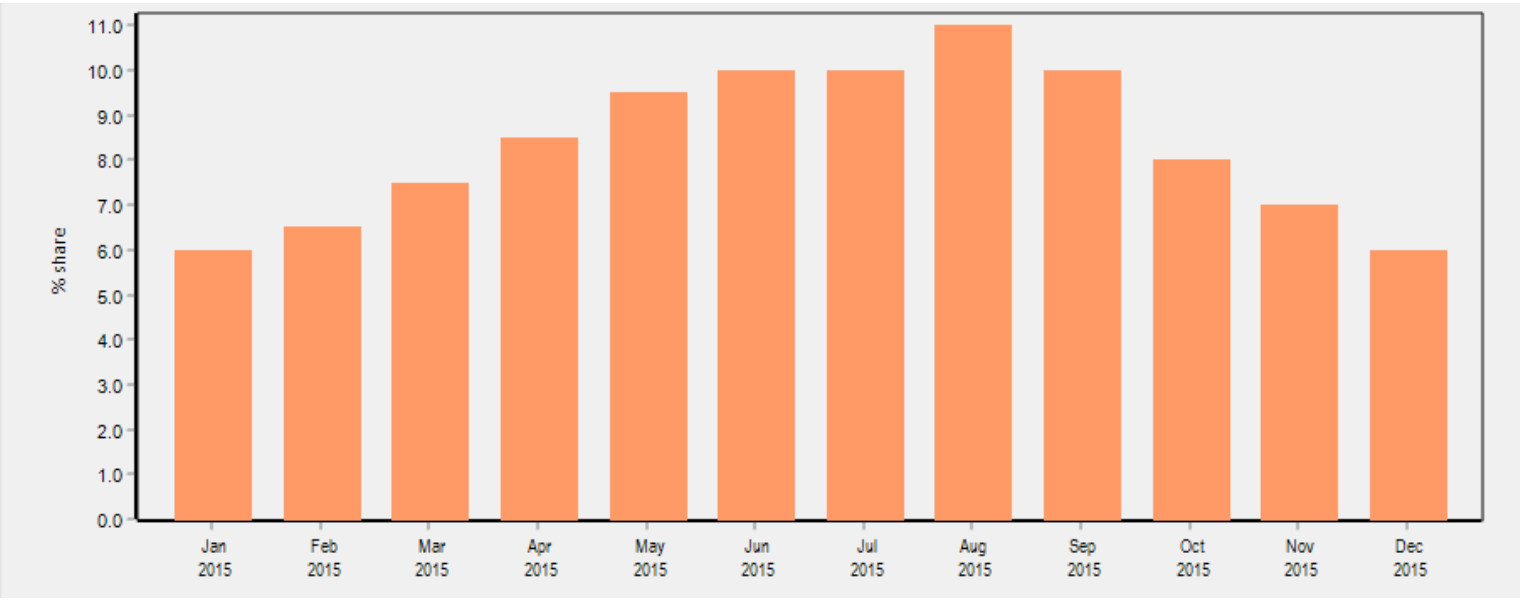

Figure 5. Non-agricultural monthly variation

\subsection{Water uses for non-agricultural}

Non-agricultural uses of water include, domestic, industrial and commercial uses. The Anbar Water Directorate has estimated the water for multipurpose uses at $\left(1011419 \mathrm{~m}^{3} /\right.$ day) and the population of Anbar about 1,771,656 persons. This means that the daily use of the areas of the upper Euphrates is equal to $\left(0.57 \mathrm{~m}^{3} /\right.$ day $)$ for non-agricultural sector in the current account (2015). Figure 5 shows the monthly variance in the consumption of the non-agricultural water use.

\section{RESULTS AND DISCUSSION}

\subsection{Develop scenarios}

The scenarios are assumptions to find suitable alternatives to the current situation, whether these alternatives are the water supply sources or prices .It shows how the system will evolve in the future continuously over time under specific political and technological conditions. The scenario analysis includes an answer to the question (what if). The results of the analysis of the proposed scenarios show the extent of their impact on the reference scenario in improving the management of water resources and choosing the best alternative [4]. The reference scenario has possessed the characteristics of the current conditions with previous methods of water management, taking into account that the population is the urban and rural population, this scenario is useful for comparison with the new scenarios. The results of the reference scenario showed that there is an increase in the demand for water from (100 to 400) MCM, as shown in Figure 6. According to the results listed in Figure 7, it can be noticed that a shortage of water amounted to (38) MCM in 2035 as calculated by WEAP model.

Based on the reference scenario, the following scenarios were analyzed:

1-The first scenario: It is the use of modern irrigation methods where irrigation efficiency increases by $30 \%$ as a result of the shift from surface irrigation systems to sprinkler irrigation, Figure 8 shows the decrease in the water demand in the agricultural sector when irrigation efficiency increases. When comparing the results with the reference scenario, it was noted that the water deficit decreased from (38 to 0) MCM, as shown in Figure 9. So, the modern irrigation systems helped to get rid of the expected future deficit.

2-The second scenario: It is the scenario of re-use of wastewater, which is liquid waste whose quality has been negatively affected as a result of human influence on them. The water deficit decreases to (35) MCM when applying this scenario, as shown in Figure 10.

3-The third scenario: Shows the change in the deficit ratio when using another resource, which is groundwater in addition to surface water, where the rate of deficit demand decreased when applied to about (16) MCM, as shown in Figure 11.

4-Fourth scenario: When applying all of the above scenarios together, the percentage of unmet water demand will be (1.9) MCM, as in Figure 12. 


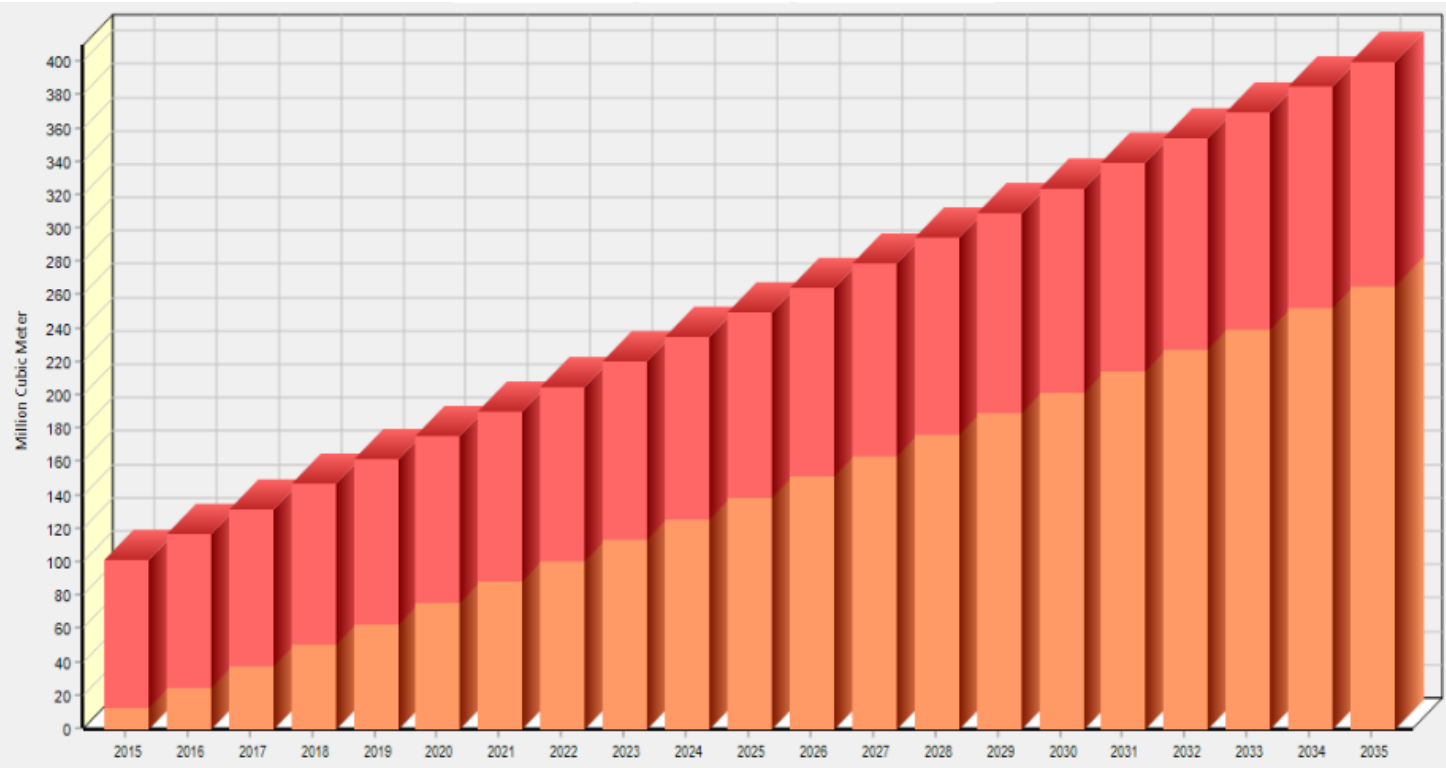

\begin{tabular}{|l|}
\hline All Branches \\
\begin{tabular}{|l|l|}
\hline$\nabla$ & Agricultural \\
\hline & non agricultural \\
\hline
\end{tabular} \\
\hline
\end{tabular}

Figure 6. Water demand (2015-2035)
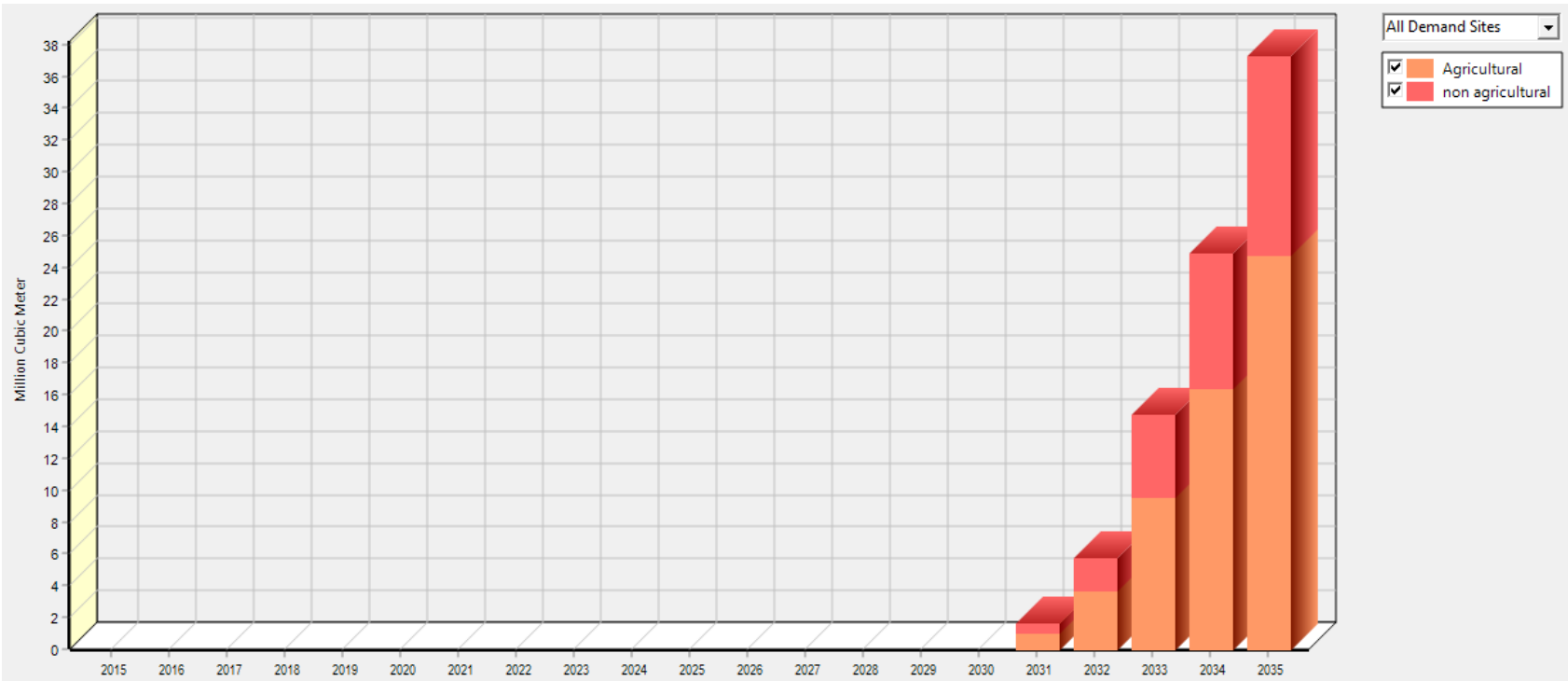

Figure 7. Water deficit by (2035)

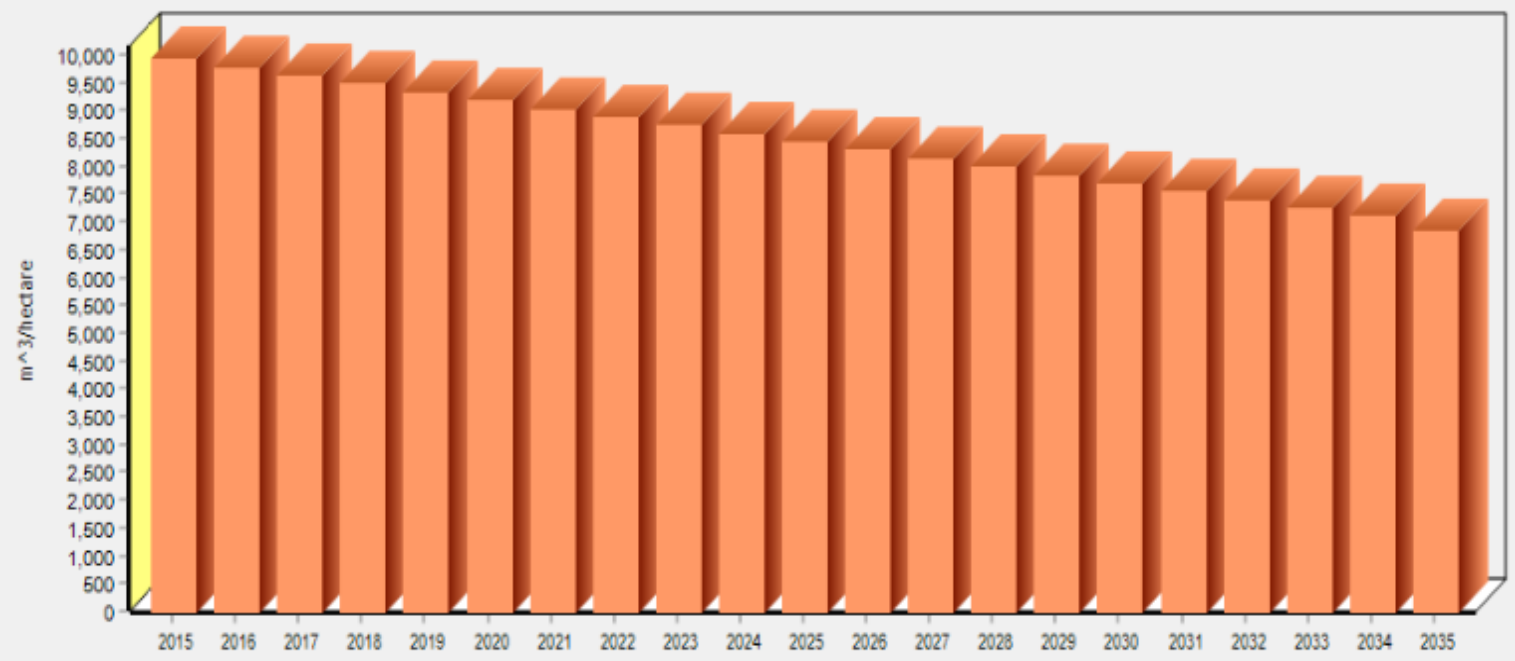

Figure 8. Reducing water demand for the agricultural sector when irrigation efficiency increases by $30 \%$ 


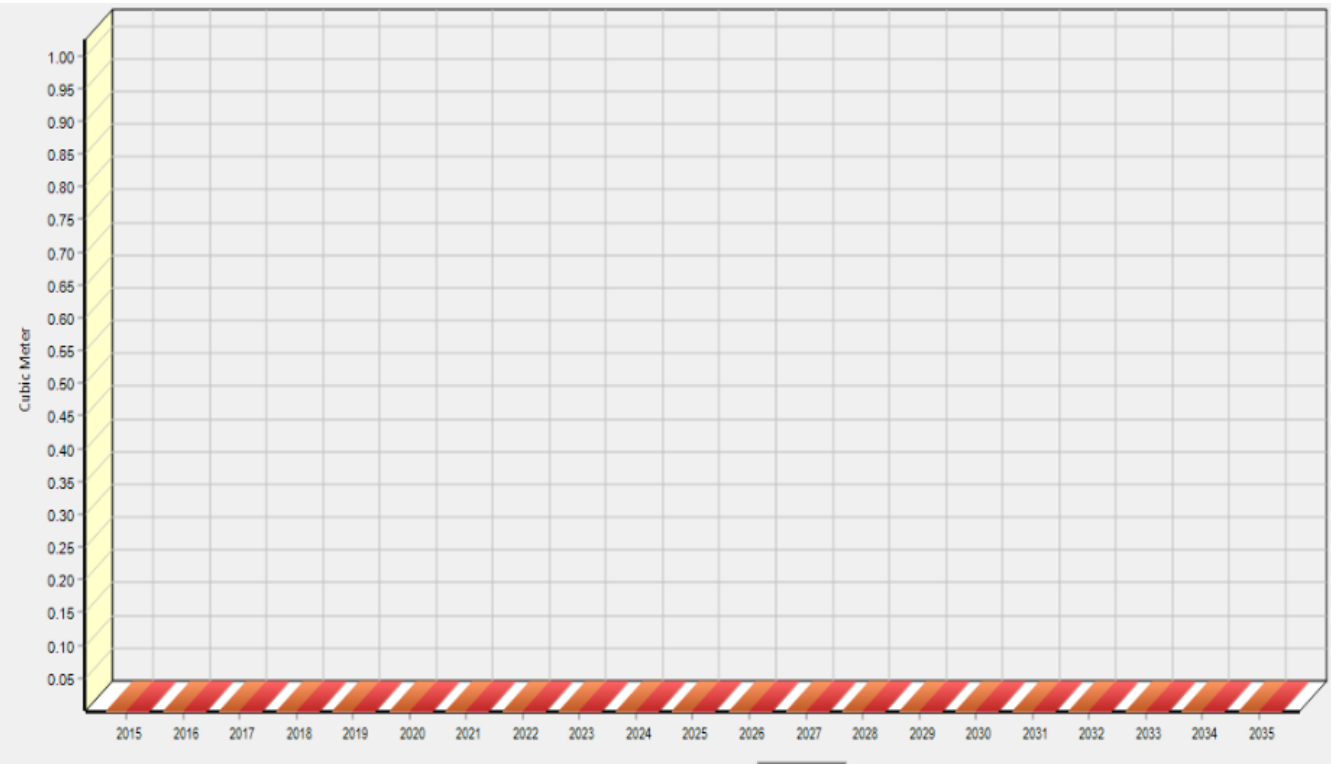

All Demand Sites

Figure 9. Water deficit when applying modern irrigation methods

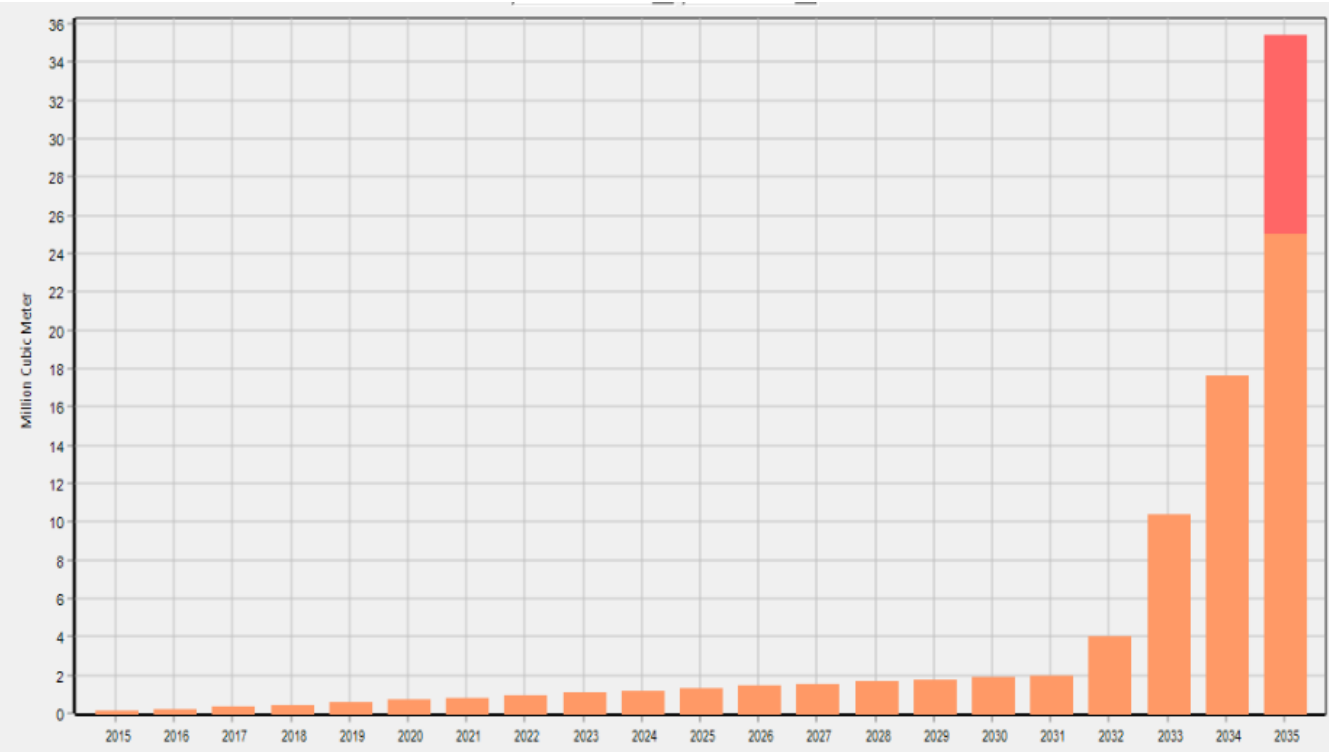

All Demand Sites

Figure 10. Water deficit with wastewater reuse scenario

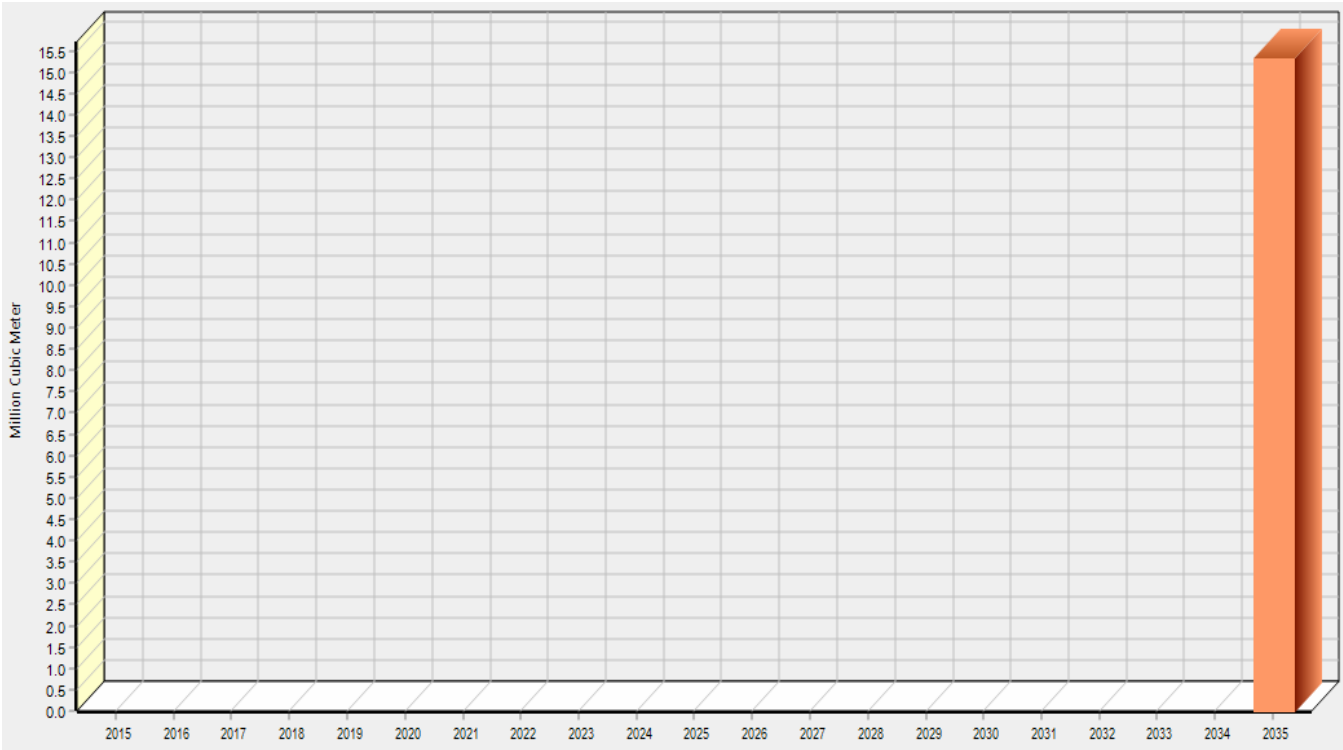

Figure 11. Water deficit with the groundwater scenario 


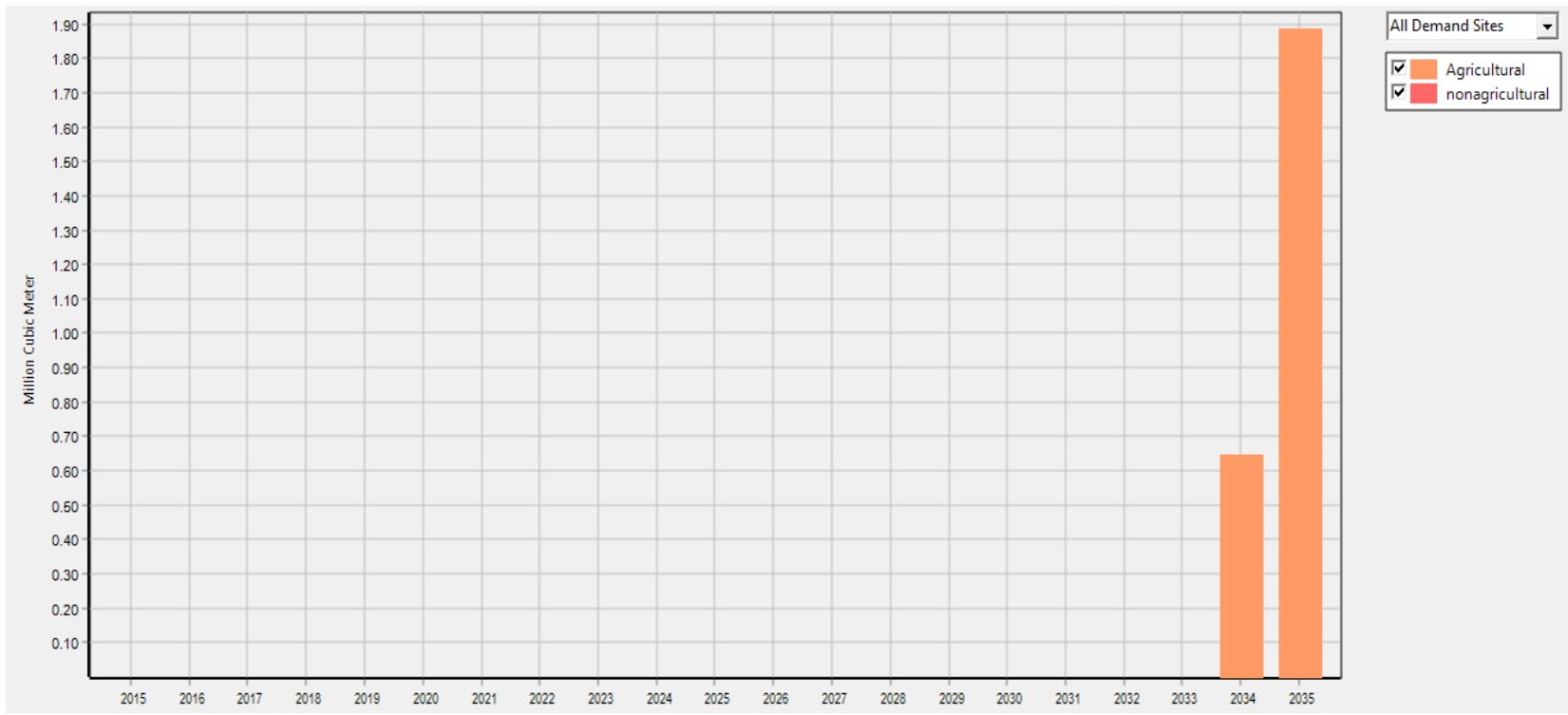

Figure 12. Decrease deficit when applying all scenarios

To achieve the sustainability of water resources and get rid of the water deficit in the study area, the proposed scenarios that contribute to reducing or eliminating the deficit must be applied. Where the most influential of the scenarios on the water deficit was the scenario of adopting modern irrigation methods that aim to increase the efficiency of irrigation, as it contributed to getting rid of all the water deficit in the study area. While the wastewater use scenario contributed to reducing the water deficit by $3 \mathrm{MCM}$, and due to the importance of wastewater, special networks must be prepared to collect this water and separate gray wastewater from black wastewater to be used for irrigation purposes or in natural landscapes. The results of the study also indicated the need to pay attention to groundwater and recharge it because it is an important water source, as it contributed to reducing the water deficit by 22 MCM. If all the scenarios are applied together, the water deficit will be reduced to $1.9 \mathrm{MCM}$.

\section{CONCLUSIONS}

Based on the results of modeling water demand in the upper Euphrates, it is possible to conclude the importance of adopting alternative methods to reducing the deficit, as shown in Figure 13. The WEAP model also showed that the WEAP model has great potential for representing water conditions. As a result of adopting four scenarios, the following conclusions can be drawn:

1. For the reference scenario, the water demand has reached $100 \mathrm{MCM}$ in 2015 , but this demand will increase to 400 MCM in 2035, exceeding the demand in the base year as a result of the population increase.

2. Water demand have been fully met by adopting modern irrigation systems, rather than by relying on surface irrigation systems.

3. The water deficit will decrease from (38 to 35) MCM, just in case of using wastewater.

4. The water deficit will be reduced from (38 to 16) MCM when groundwater is used as an additional source of water supply.

5. The water deficit will be reduced to $1.9 \mathrm{MCM}$ in 2035 When all scenarios are applied.
Deficit (MCM)

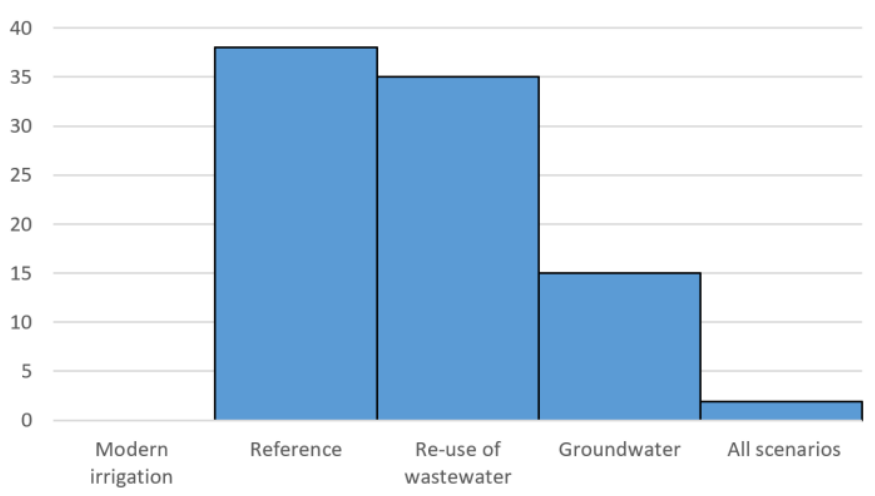

Figure 13. Water deficit when using alternative scenarios

\section{REFERENCES}

[1] Al-Ansari, N. (2013). Management of water resources in Iraq: Perspectives and prognoses. Engineering, 5(6): 667-684. https://doi.org/10.4236/eng.2013.58080

[2] Al-Ansari, N., Ali, A., Knutsson, S. (2014). Present conditions and future challenges of water resources problems in Iraq. Journal of Water Resource and Protection, 6(12): 1066-1098. https://doi.org/10.4236/jwarp.2014.612102

[3] Al-Muqdadi, S.W., Omer, M.F., Abo, R., Naghshineh, A. (2016). Dispute over water resource management-Iraq and Turkey. Journal of Environmental Protection, 7(8): 1096-1103. https://doi.org/10.4236/jep.2016.78098

[4] Metobwa, O.G.M., Mourad, K.H.A., Ribbe, L. (2018). Water demand simulation using WEAP 21: A case study of the Mara River Basin, Kenya. International Journal of Natural Resource Ecology and Management, 3(1): 9-18. https://doi.org/10.11648/j.ijnrem.20180301.12

[5] Sarhan, R. (2015). Integrated Management of Water Recourses in Al-Raggad Basin. MSc. Thesis; Damascus University, Engineering School, Department of Water Engineering, Syria. http://mohe.gov.sy/master/Message/Mc/roqia\%20sarhan .pdf. 
[6] Sanjaq, L.M. (2009). The Use of Water Evaluation and Planning "WEAP" Program as a Planning Tool for Jerusalem Water Undertaking" JWU" Service Area. https://hdl.handle.net/20.500.11888/7559

[7] Jaradat, N.E.A.M.M. (2010). Evaluation of Water Resources Management Options in Gaza Strip using WEAP (Doctoral dissertation). https://hdl.handle.net/20.500.11888/7555

[8] Jaber, A.Z. (2018). WEAP modeling for effective management of water demand and supply in Shatt AlHillabasin - Iraq. International Journal of Civil Engineering and Technology (IJCIET), 9(13): 290-302.

[9] Al-Eisa, A.A.K. (2014). Management of Water Resources in Bahr An-Najaf Region. MSc Thesis, Faculty of Engineering, Civil Engineering Department, University of Kufa, Iraq.

[10] Rasul, H.A., Askar, M. (2010). Integrated Water Resources Management for Alana Valley in Kurdistan Region - Iraq MSc thesis, Salahaddin University-Hawler, Iraq.

https://www.weap21.org/Downloads/IWRM_for_Alana _Valley.pdf.

[11] Mourad, K.A. (2012). Marginal and Virtual Water for Sustainable Water Resources Management in Syria. Division of Water Resources Engineering, Faculty of Engineering, Lund University. https://portal.research.lu.se/ws/files/4312484/3048005.p df.

[12] Alhayek, H. (2018). Touristic rehabilitation of archaeological sites in Syria-The Aga Khan Foundation experience between the past and the future (Doctoral dissertation, Universidade de Coimbra), 4(5): 191-204.

[13] Hussein, I., Al-Weshah, R. (2009). Optimizing the water allocation system at Jordan valley through adopting water evaluation and planning system model (WEAP). In 13th International Water Technology Conference Proceedings, Hurghada, Egypt, pp. 12-15.

[14] Sulaiman, S.O., Kamel, A.H., Sayl, K.N., Alfadhel, M.Y. (2019). Water resources management and sustainability over the Western desert of Iraq. Environmental Earth
Sciences, 78(16): 1-15. https://doi.org/10.1007/s12665019-8510-y

[15] Hussien. B. (2010). Hydrogeologic conditions within alanbar governorate. Journal of Anbar University for Pure Science, 4(3): 97-111.

[16] Mounir, Z.M., Ma, C.M., Amadou, I. (2011). Application of water evaluation and planning (WEAP): A model to assess future water demands in the Niger River (in Niger Republic). Modern Applied Science, 5(1): 38

[17] Yang, L., Bai, X., Khanna, N. Zh., Yi, S., Hu, Y., Deng, J., Gao, H., Tuo, L., Xiang, S., Zhou, N. (2018). Water evaluation and planning (WEAP) model application for exploring the water deficit at catchment level in Beijing. Desalination and Water Treatment, 118: 12-25. https://doi.org/10.5004/dwt.2018.22332

[18] Stockholm Environmental Institute (SEI). (2016). "WEAP Tutorial". https://www.weap21.org/downloads/WEAP_Tutorial.pd f.

[19] Najm, A. B. A., Al-bayati, I. M. A., and Sulaiman, S. O. (2021). Improving the cultivated area for the Ramadi Irrigation Project by using Water Evaluation and Planning Model (WEAP). Al-Rafidain Engineering Journal (AREJ), 26(1): 105-114 https://doi.org/10.33899/rengj.2020.128248.1063

[20] Mohammad, S., Mustafa, A., Al-Somaydaii, J. (2020). Sustainable management of water resources in the upper Euphrates Basin-Iraq. Anbar Journal of Engineering Sciences, 8(4): 308-317.

[21] JICA (Japan International Cooperation Agency). (2016). Data Collection Survey on Water Resource Management and Agriculture Irrigation in the Republic of Iraq, Final Report. 7R, JR, 16-008. https://openjicareport.jica.go.jp/pdf/12253860.pdf.

[22] Najm, A.B.A., Abdulhameed, I.M., Sulaiman, S.O. (2020). Water requirements of crops under various Kc coefficient approaches by using Water Evaluation and Planning (WEAP). International Journal of Design \& Nature and Ecodynamics, 15(5): 739-748. https://doi.org/10.18280/ijdne.150516 